Article

\title{
Do Firms R\&D Collaborations with the Science System and Enterprise Group Partners Stimulate Their Product and Process Innovations?
}

\author{
Samuel Amponsah Odei *(i) and Jan Stejskal 1 \\ Faculty of Economics and Administration, University of Pardubice, 53009 Pardubice, Czech Republic; \\ jan.stejskal@upce.cz \\ * Correspondence: samuelamponsah.odei@upce.cz; Tel.: +420-735-234-511
}

Received: 4 December 2018; Accepted: 6 May 2019; Published: 9 May 2019

\begin{abstract}
There is a growing consensus that knowledge drives firms' process and product innovations. An important source of these innovations is from firms networking with R\&D partners, such as those in the science system and other industries in the enterprise group. This paper aimed to examine firms' innovation collaborations with science systems and enterprise group partners and how these influence their product and process innovations. We focused on firms in the manufacturing sectors in the Czech Republic and Hungary. For our empirical analysis, we used the truncated data from the Eurostat Community Innovation Survey (CIS) 2012-2014, and the binary logistic regression model. Our results have demonstrated that firms' collaborations with these actors have a discernible positive influence on their product innovations. Conversely, the collaborations with these R\&D partners for process innovations produced mixed results for both countries.
\end{abstract}

Keywords: science system; knowledge; process innovations; product innovations; collaborations; Czech Republic; Hungary

JEL Classification: L60; 030; 031; 052

\section{Introduction}

In recent decades, there is a paradigm shift from conducting innovations in isolation to the collaborative innovation models where firms cooperate and depend on other R\&D partners for their knowledge and innovations. The interactions of universities, industries, and governments have been described by Leydesdorff (2012) as 'neo-institutional arrangements,' which can be made the subject of social network analyses. Social institutions, such as the science system (universities and other public research organizations), and other industries in the enterprise group have begun mutually beneficial collaborations and interactions. A multitude of studies on research and development (R\&D) collaborations have demonstrated that these partnerships are essential for achieving product and process innovations because they enable firms' access to the external knowledge they need to innovate and transform their products and processes (Un et al. 2010; Wu 2012; Feller et al. 2013).

However, the existing literature reviewed revealed some caveats that raise doubts about the general applicability of the results of these innovation collaborations between the science system actors and firms in the enterprise group. For instance, most of these empirical studies focused on countries classified as innovation leaders and those with strong innovation potential, such as the United Kingdom, Denmark, France, Germany, and Sweden among others (Banal-Estañol et al. 2015; Kergroach et al. 2018; Liu et al. 2019). These studies demonstrated that these R\&D collaborations are noticeable in these innovation leaders and strong innovative countries, but they differ significantly and 
are almost completely rare in new EU countries, such as Hungary and the Czech Republic, classified as moderate innovators still undergoing structural changes from communism to market economies. There are huge socioeconomic and innovation gaps between strong and moderate innovative countries and this may have an impact on the expected generalization of the results of these studies on innovation collaborations as a one size fits all approach. Due to these differences in innovation potentials, factors promoting successful innovation collaborations and sources of innovations used by strong innovation leaders can therefore not be applicable to moderate innovative countries, like the Czech Republic and Hungary. Hence, more empirical evidence from moderate innovators and transition countries are greatly desirable.

Recent studies on innovation activities in the Czech Republic by Prokop and Stejskal (2017) and Prokop et al. (2017) focused on the factors driving firms' innovations, but did not focus on firms' R\&D collaborations and how they influence product and process innovations. In Hungary, studies by Hashi and Stojčić (2013) and Zygmunt (2017) assessed the impact of innovation activities on firms' innovation performance. In this article, we address this gap by empirically examining the relationship between firms' collaborations with other firms in enterprise groups, universities, and government research institutions and how they can potentially influence product and process innovations. We aim to examine whether firms in the manufacturing sectors in both countries' product and process innovations are influenced by their collaborations with these R\&D partners.

Innovation is the consequence of the various interactions that exist between these social actors and institutions, and these numerous interactions have become known as the national innovation system (Nelson 2013). Innovations result from the constant interactions, and communication and feedback sharing among these various social actors. These collaborations have three dimensions and flow of resources and outputs in the form of knowledge and innovation between universities, industries, and governments research organizations (Leydesdorff 2012). These collaborations or interactions lead to the transformation of knowledge produced by the science system into innovation.

Firms' R\&D collaborations are increasingly becoming a vital source of innovation. Firms' cooperation with partners, such as universities, other enterprises, and government research institutions, results in innovations, which subsequently drive and improve their productivity. Innovation is defined by Crossan and Apaydin (2010) as the "production or adoption, assimilation, and exploitation of a value-added novelty in economic and social spheres; renewal and enlargement of products, services, and markets; development of new methods of production; and establishment of new management systems. It is both a process and an outcome" (p. 1155). In this paper, we focused on two types of innovations: Product and process. Product innovation simply refers to the ability of firms to introduce significantly new and improved goods or services to the market whilst process innovation entails the implementation of new or significantly improved methods of production or deliveries (Hervas-Oliver et al. 2014). Process innovation involves the creation and application of new ideas and methods by manufacturing companies (Trantopoulos et al. 2017). This encompasses several industrial activities, such as advanced changes in the production process, introduction of new equipment, and new management practices. Firms resort to large scale process development when they are in intense competition with rivals in the same market (Un and Asakawa 2015).

The main motivation for selecting the Czech Republic and Hungary for our analysis is because they are currently the best performing and biggest economic giants among the Visegrad group of countries (Ivanová and Masárová 2018), but less is known about firms' R\&D collaborations for knowledge and innovations in these countries. In this paper, we focused on the manufacturing industries in both countries. The manufacturing sectors in these countries contribute decisively to their economies' health, employment, and driving increases in wages and salaries. For instance, the automotive industry alone in the Czech Republic employs about 120,000 people and contributes about $47.3 \%$ to the GDP (Dvořák et al. 2017). Similarly, in Hungary, the manufacturing sector accounts for about one quarter of the country's GDP and attracts foreign direct investments (FDI) to the tune of about EUR 71.6 billion, the highest amount in Central and Eastern Europe (Brada and Singh 2017). Due to the significant 
contributions these industries in both countries provide, we assess their sources of knowledge and innovations by focusing on whether their collaborations with partners in the science system and enterprise group influence their products and process innovation. We focused on these selected R\&D partners because the science system is the hub of research that can be appropriated by firms for their innovation activities. Also, we considered the enterprise group as a source of firms' knowledge and innovation because of the continuous interactions among partners. Sharing centralized innovation decisions means these firms in the group are under compulsion to implement these innovative decisions taken collectively by seeking new knowledge that can be transmuted into innovation.

The rest of the article is organized as follows. The next section describes the empirical and theoretical literature that explores the sources of firms' product and process innovations. Section 3 focuses on the methodology, the variables used, and presents the source of the dataset. The empirical results and the test of their robustness by means of the binomial logistic regression are included in Section 4 , and Section 5 discusses the results in the perspective of the existing literature. The final part concludes with recommendations and suggestions for further research.

\section{Theoretical Background and Hypotheses Development}

Firms' product and process innovations increasingly depend on their ability to absorb and assimilate external knowledge, information, and technologies. An important source of knowledge and innovations that can improve firms' economic competitiveness can be from their internal confines. Externally, they can also collaborate with other partners for these innovations. Firms can derive their innovations from their internal ecosystem by carrying out regular in-house activities, such as trainings and workshops, among others. They can also derive their innovations externally by forming synergies with other partners, such as the science system (universities and public research organizations), that are the birthplaces of knowledge and research. Also, externally, firms' interactions with other partners in the market environment, such as those in their enterprise group, can stimulate them to adopt innovative measures (Maietta 2015). The relationship between these social actors results in knowledge flows and appropriation resulting in innovations (Huggins et al. 2008). The constant interactions, communications, and feedback sharing among these social entities enable them to gain vital knowledge that can influence their innovation activities (Zhang et al. 2016).

These external innovation collaborations can help firms to overcome their innovation barriers and allow them access to knowledge, which is seen as vital in the innovation process (West and Bogers 2014). Firms' innovation collaborations with other partners in the science system and their enterprise group increases the likelihood of accomplishing innovations (Belderbos et al. 2015).

Universities and public research organizations are the center of research activities that have become the engines of industrial innovations (Perkmann et al. 2013). Firms' collaborations with universities as well as other higher educational institutions (public research institutions inclusive) form an imperative source of knowledge transfers (Odei and Stejskal 2018a). Universities generate new ideas, providing skilled human capital in tandem to their knowledge creation competence. According to Foray and Steinmueller (2003), universities and other public research centers have a crucial role to play in creating knowledge and translating it into innovative products and services, in close cooperation with businesses. Public research institutes (PRIs) also play similar roles to universities with slight variations in their activities. Universities perform the dual functions of research and teaching, whereas PRIs solely offer direct R\&D support to public authorities and firms.

Universities and PRIs can primarily be relied upon to achieve product innovations and conduct basic research into particular technologies (Tether 2002). Universities and PRIs are significant sources of knowledge for firms' innovations, especially in emerging technologies. When firms partner with universities and PRIs, they stand a good chance of introducing onto the market new or significantly improved goods and services that give them the competitive edge over their market rivals (Wu 2014). Firms' collaborations with universities and PRIs permit them to have access to how industrial processes are conducted, and this helps them to improve upon their product quality, thereby making them highly 
efficient. These R\&D collaborations allow university researchers to gain detailed insight into industrial processes and this positions them better to provide advisory or consultancy services that can help in improving their innovations (Kim et al. 2006). Firms can have access to universities' academic research, which they can morph into innovative products and services when they collaborate (Kempton 2015). According to Belderbos et al. (2015), firms' innovation collaborations with universities and other public research organizations are seen as the most effective means to achieve innovations envisioned to open firms to new markets. Countries characterized as having low innovative potentials have low innovation capacities due to less support from their governments. The lack of a well-established balance in public finances swells the interest rate and makes financing less available for the private sector, leading to what has become known as the crowding-out effect. This makes firms unable to rely on the financial market's borrowing to support their innovation activities. This results in low levels of investment in research and development. To avoid or overcome these low R\&D potentials, firms will have to collaborate efficiently with knowledge and R\&D hubs, such as universities and other public research organizations. We summarize this understanding that firms engaging in R\&D collaborations with knowledge producers, such as universities and other public research organizations, may result in higher probabilities of generating and introducing product and process innovations than their collaborations with other R\&D partners, and as such, we therefore hypothesize that:

Hypothesis 1. For manufacturing firms, RED collaborations with science system partners are highly likely to result in product innovations than process innovations.

The enterprise group can be a vital source of both product and process innovations for firms. The enterprise group consists of the associations of enterprises that are connected to each other legally or financially with a centralized command. Firms in the enterprise group have numerous decision-making procedures and centers, and these decision-making processes can influence their product and process innovations. Firms that are part of an enterprise group are inclined to cooperate among themselves for their product and process innovation (Mohnen and Hoareau 2003). Studies conducted by Busom and Fernández-Ribas (2008) concluded that firms that are part of an enterprise group prefer to collaborate among themselves for their innovations. Firms belonging to a group stand a lofty chance of benefiting from enhanced communication structures and are well-informed about possible methods and new techniques to improve their products and processes (Hottenrott and Lopes-Bento 2014). In countries with low innovation potential, the prospects of firms collaborating with science system partners are low because these knowledge institutions do not generate commercially viable $R \& D$ that can be appropriated by industries. So, firms, especially in the same enterprise group, are likely to collaborate for their knowledge and other innovation needs. These collaborations among firms in the group will help to minimize the high cost of innovating in isolation, improving their access to diverse knowledge that can help to improve their innovation performances.

We conclude and build on the idea that firms' continuous collaborations with other industries in their enterprise group enable them to access complementary knowledge and information that can influence their innovations rather than with different R\&D collaborators. Thus, we offer the following hypothesis:

Hypothesis 2. For manufacturing firms, their RED collaborations with other partners in the enterprise group are more likely to result in product innovations.

Hypothesis 3. Firms' RED collaborations with other partners in the enterprise group are less likely to improve their process innovations.

The literature has suggested that a certain number of industry and firm variables could affect the possibilities of innovation within firms. Firm characteristics, such as its size and ownership, play potential roles and impact on firms' innovation potentials. Firm size is an important factor that 
has widely been used to determine the probability of firms' collaborations with other R\&D partners (Laursen and Salter 2014). Firm size can influence firms' collaborations as well as their decisions to procure new equipment and expertise to improve their processes and product. Large firms are more probable to collaborate with other partners, such as universities, and other public research institutions for their R\&D (Mohnen and Hoareau 2003). This is because large firms have the financial endowments and research intensity (human resource base) needed to embark on R\&D. A research by Tether (2002) concluded that large firms are preferred for collaborations than smaller and medium enterprises (SMEs). Conversely, SMEs are branded as having decreasing R\&D economies of scale, hampered by inadequate expertise and funding needed to execute in-house innovation activities (Chun and Mun 2012). Numerous studies have found a direct relationship between process innovations and firm size (e.g., Forés and Camisón 2016). These findings are consistent with the literature on technology adoption and the role of firm size in shaping the potential of firms to adopt new technologies. As suggested by these studies, it can be expected that large firms will be more likely to be product and process innovators because they have the resource capabilities (Damanpour 2010).

Similarly, firm ownership can also influence their product and process innovation potentials. Owners of firms can influence its innovation activities by undertaking new initiatives aimed at affecting their abilities to introduce new products or processes, as well as helping to find suitable markets for exports. Foreign ownership relates to a ballooned likelihood of innovations due to their higher spending on in-house R\&D activities. Foreign owned firms are more probable to invest in the acquisition of external knowledge than locally owned firms (Sasidharan and Kathuria 2011). Multinational firms transfer higher technologies in the form of new products and processes to developing countries using their subsidiaries (Pietrobelli and Rabellotti 2011). Foreign owned firms are more likely to introduce new products or processes than locally owned firms. However, studies conducted by Crespi and Zuniga (2012) produced mixed results for selected Latin American countries; multinational firms had significant and positive influence on R\&D in Uruguay, Argentina, and Panama, but the results were negative in Costa Rica, Chile, and Colombia. Foreign-owned firms or those part of multinational groups gain from both economies of scope and scale and are endowed with vigorous financial strength to invest in innovation and its related activities. They are better positioned than locally owned firms to attract skilled labor and acquire advanced equipment needed for innovation activities (Criaco et al. 2014). Hence, foreign-owned firms are more likely to build innovation networks with universities and PRIs as well as other partners in their group.

\section{Data and Variable Description}

We used data from the anonymized Community Innovation Survey (CIS) conducted between 2012 and 2014 for our empirical analysis. CIS provides harmonized information about innovation activities in enterprises and it centers on the various aspects of developing firm-level innovations, providing detailed information on firms' sources of knowledge and information, public funding, and innovation expenditures. In accordance with the literature (see Bolli and Woerter 2013), we sampled a total of 6191 manufacturing industries (both large and SMEs) that carried out R\&D activities in the period 2012-2014 in the Czech Republic and Hungary (3069 and 3122, respectively).

The dependent variables used for these analyses are binary in nature, providing information on whether firms collaborated for their innovation or not. They include:

- $\quad$ Firms' collaboration with other enterprises within their enterprise group (COENG).

- Firms' collaboration with universities and other higher educational institutions (COUNI).

- Collaboration with public research institutions (COGOV).

The independent variables used in our models focused on product and process innovations and they include:

- Introduced onto the market a new or significantly improved good (INPDGD). 
- Introduced onto the market a new or significantly improved service (INPDSV).

- Introduced onto the market a new or significantly improved method of production (INPSPD).

- Introduced onto the market a new or significantly improved logistic, delivery, or distribution system (INPSLG).

- Introduced onto the market new or significantly improved supporting activities (INPSSU).

\subsection{Control Variables}

We also considered other firm characteristics that can stimulate firms' innovations and R\&D collaborations as our control variables. We included two control variables that have frequently been used to correlate closely with a firm's collaboration. They are firm size, measured as the log number of total employees in the firm (based on this classification, firms can be lumped into large firms or small and medium Enterprises (SMEs)), and ownership measured by if the firm is local or foreign owned.

\subsection{Empirical Model}

The binomial logistic regression was used for this study due to the dichotomous nature of the dependent variables (types of collaborations). The binomial logistic model explains the variations in firms' collaborations based on the changes in the independent variables. The model works on the assumption that the dependent variable is a linear function of the independent variables with an error term $(\varepsilon \mathrm{i})$. The study has assumed that the relationship between firms' R\&D collaborations and their product and process innovations is a linear function. The general formula for the binomial logistic regression is given by Tranmer and Elliot (2008) as follows:

$$
\ln \left[P_{i} /\left(1-P_{i}\right)\right]=\beta_{0}+\beta_{1} X_{1 i}+\beta_{2} X_{2 i}+\cdots+\beta_{k} X_{k i}
$$

The reduced form of the binomial logistic model can be expressed as:

$$
\text { Coll }=\alpha+\beta i X i+\varepsilon,
$$

where:

$$
\begin{aligned}
& \text { Coll = a firm's collaboration; } \\
& \alpha=\text { the intercept; } \\
& \beta i=\text { regression coefficients; } \\
& \text { Xi = independent variables; } \\
& \varepsilon=\text { the error term. } \\
& \text { COLL }=\beta_{0}+\beta_{1} \text { INPDGD }_{i}+\beta_{2} \text { INPDSV }_{i}+\beta_{3}+\mathrm{INPSPD}_{\mathrm{i}}+\beta_{4} \mathrm{INPSLG}_{\mathrm{i}}+\beta_{5} \mathrm{INPSSU}_{\mathrm{i}}+\varepsilon_{\mathrm{i}} .
\end{aligned}
$$

To be able to ascertain whether a firm's collaborations with actors in the science system and the enterprise group influence their process and product innovations, we ran three separate models for each country. The results are explained in the next section.

\section{Results and Discussion}

The explanatory powers of our binomial logistic models range between $2 \%$ and $47 \%$, and the low levels of the model's predictive powers indicate that the possibilities of these innovation collaborations in the two countries are at lower levels. This does not take away the fact that our regression models have statistically significant explanatory and predictive powers.

Table 1 provides the results of the tests of the hypotheses for Hungary. The results show that our Hypothesis 1 is fully supported, while Hypothesis 2 is also fully supported. However, our Hypothesis 3 is somewhat supported. The results for Hypothesis 3 showed that firms' collaborations with other partners in the enterprise group only improved supporting activities for processes, but did not improve their manufacturing or logistics methods. The results show that firms' product innovations are 
positively associated with their R\&D collaborations. When firms collaborate with other industries in the enterprise group, universities and government research institutions, they are highly probable to introduce onto the market new or significantly improved goods as well as services. This implies that the firms in Hungary can improve their product innovations when they collaborate with these $R \& D$ partners. This is particularly true because universities and other public research organizations are the birthplaces of knowledge that are the heart of the innovation process. Our result is consistent with the numerous studies that concluded that firms' collaborations with universities, industries, and governments' research centers influence their innovations (Prokop et al. 2017; Johnston and Huggins 2017; Braunerhjelm et al. 2018).

Table 1. Regression results for Hungary.

\begin{tabular}{|c|c|c|c|c|c|c|}
\hline \multicolumn{3}{|c|}{ COENG } & \multicolumn{2}{|c|}{ COUNI } & \multicolumn{2}{|c|}{ COGOV } \\
\hline Variables & B (S.E) & $\operatorname{Exp}(B)$ & B (S.E) & $\operatorname{Exp}(B)$ & B (S.E) & $\operatorname{Exp}(B)$ \\
\hline \multicolumn{7}{|l|}{$\begin{array}{c}\text { Product } \\
\text { innovations }\end{array}$} \\
\hline INPDGD & $\begin{array}{c}1.861^{* * *} \\
(0.439)\end{array}$ & 6.429 & $\begin{array}{c}1.807^{* * *} \\
(0.277)\end{array}$ & 6.093 & $\begin{array}{c}1.828^{* * *} \\
(0.554)\end{array}$ & 6.223 \\
\hline INPDSV & $\begin{array}{l}0.880 * \\
(0.484)\end{array}$ & 2.411 & $\begin{array}{l}0.809 * * \\
(0.332)\end{array}$ & 2.247 & $\begin{array}{l}1.249 * * \\
(0.508)\end{array}$ & 3.488 \\
\hline \multicolumn{7}{|l|}{$\begin{array}{c}\text { Process } \\
\text { innovations }\end{array}$} \\
\hline INPSPD & $\begin{array}{c}0.561 \\
(0.416)\end{array}$ & 1.752 & $\begin{array}{l}1.080^{* * * *} \\
(0.267)\end{array}$ & 2.947 & $\begin{array}{c}0.750 \\
(0.508)\end{array}$ & 3.488 \\
\hline INPSLG & $\begin{array}{l}-0.950 \\
(0.647)\end{array}$ & 0.387 & $\begin{array}{c}-0.963 \text { ** } \\
(0.402)\end{array}$ & 0.382 & $\begin{array}{l}-0.474 \\
(0.719)\end{array}$ & 0.623 \\
\hline INPSSU & $\begin{array}{l}0.739 * * \\
(0.580)\end{array}$ & 3.648 & $\begin{array}{l}1.511^{* * *} \\
(0.289)\end{array}$ & 4.531 & $\begin{array}{c}0.226 \\
(0.596)\end{array}$ & 1.254 \\
\hline \multicolumn{7}{|l|}{ Control variables } \\
\hline Locally owned & $\begin{array}{l}1.294^{* *} \\
(0.580)\end{array}$ & 3.648 & $\begin{array}{c}0.440 \\
(0.496) \\
\end{array}$ & 1.552 & $\begin{array}{l}-0.066 \\
(0.724)\end{array}$ & 0.936 \\
\hline Foreign owned & $\begin{array}{l}-0.653 \\
(0.574)\end{array}$ & 0.520 & $\begin{array}{l}-0.083 \\
(0.429)\end{array}$ & 0.920 & $\begin{array}{l}-0.945 \\
(0.627)\end{array}$ & 0.389 \\
\hline Large firms & $\begin{array}{c}0.657 \\
(0.613)\end{array}$ & 1.929 & $\begin{array}{l}2.261^{* * * *} \\
(0.411)\end{array}$ & 9.595 & $\begin{array}{l}1.773 \text { ** } \\
(0.701)\end{array}$ & 5.890 \\
\hline SMEs & $\begin{array}{c}0.227 \\
(0.559)\end{array}$ & 1.255 & $\begin{array}{c}1.412^{* * *} \\
(0.354)\end{array}$ & 4.104 & $\begin{array}{c}0.170 \\
(0.701)\end{array}$ & 1.185 \\
\hline $\begin{array}{c}\text { Constant } \\
\text { Model fit statistics }\end{array}$ & $\begin{array}{l}-4.912 * * * \\
(0.816)\end{array}$ & 0.000 & $\begin{array}{l}-5.810 * * * \\
(0.557)\end{array}$ & 0.003 & $\begin{array}{l}-5.741^{* * *} \\
(0.859)\end{array}$ & 0.000 \\
\hline Observations & \multicolumn{2}{|c|}{3122} & \multicolumn{2}{|c|}{3122} & \multicolumn{2}{|c|}{3122} \\
\hline -2loglikelihood & \multicolumn{2}{|c|}{232.93} & \multicolumn{2}{|c|}{567.97} & \multicolumn{2}{|c|}{214.33} \\
\hline Cox \& Snell $\mathrm{R}^{2}$ & \multicolumn{2}{|c|}{0.062} & \multicolumn{2}{|c|}{0.106} & \multicolumn{2}{|c|}{0.028} \\
\hline Nagelkerke $\mathrm{R}^{2}$ & \multicolumn{2}{|c|}{0.451} & \multicolumn{2}{|c|}{0.393} & \multicolumn{2}{|c|}{0.284} \\
\hline$X^{2}(d f)$ & \multicolumn{2}{|c|}{177.941} & \multicolumn{2}{|c|}{314.69} & \multicolumn{2}{|c|}{80.79} \\
\hline
\end{tabular}

Source: Own calculations. Legend: Standard errors in parentheses, statistical significance ${ }^{* * *} p<0.01, * * p<0.05$, ${ }^{*} p<0.1$.

However, when it comes to firms' process innovations, the study has demonstrated that there is a positive and statistically significant correlation between firms' collaborations with universities and their propensity to introduce onto the market a new or significantly improved method of production. This implies that when firms collaborate with universities, they can increase their process innovations. 
Knowledge gained by graduates from universities can help firms to improve upon their production process when they collaborate either for the short or long term.

Furthermore, there is a statistically significant, but a negative relationship between firms' collaborations and their ability to introduce onto the market a new or significantly improved logistic, delivery, or distribution system. This implies that firms' collaborations with universities is probable to have an adverse effect on their likelihood of offering to the market an improved logistic delivery or distribution system. This can be attributed to the fact that universities do not deal in logistics, but produce knowledge and human capital (Odei and Stejskal 2018b).

Additionally, there is a statistically significant and positive association between a firm's collaborations and their process innovations. When firms collaborate with other enterprises in their group and universities, they are highly likely to introduce onto the market new or significantly improved supporting activities. These supporting activities include technological development, procurement systems, human resource (HR) management, company infrastructure, etc. Collaborations with other enterprises in the group can help firms improve their technology, procurement systems, and company infrastructure. Analogously, collaborations with universities can also help firms to overcome their manpower constraints (Criaco et al. 2014).

The control variables in our models behaved in a manner consistent with conventional expectations. There is statistically significant and positive association between locally owned firms' propensity to collaborate. Locally owned firms in Hungary are to a large extent probable to collaborate with other enterprises in the group, whilst multinational firms do not collaborate with firms in the enterprise, universities, and with government research institutions. Correspondingly, larger firms demonstrated a positive statistically significant association and collaboration propensities, meaning they were highly probable to collaborate with universities and public research organizations in Hungary for their innovations (Bstieler et al. 2015), whilst SMEs collaborated with only universities.

At the polar end, the result in the Czech Republic is akin to that of Hungary described above. It can be seen from Table 2 that Hypothesis 1 is fully supported whilst our Hypothesis 2 is also fully supported. The results show that although Hypothesis 3 was somewhat rejected, this was not true for all the variables for process innovations. Firms' collaborations with enterprise group partners improved their process innovation activities, such as improved production methods and improved supporting activities for their processes. Firms' collaborations with universities and government research organizations were positive and statistically significant in influencing the product innovations in these firms. This means that when firms collaborated with science system partners, they stood a good chance of introducing onto the market new or significantly improved goods and services. With regards to firms' process innovations, their collaborations with universities and government research organizations were all positive and statistically significant. This is because the codified and embodied knowledge as well as the technological development and innovations generated in these knowledge centers can be taken up by innovative firms. Collaborations with other enterprises in the group, with universities, and government research organizations to a large extent impacted on the probability of these firms to introduce onto the market a new or significantly improved methods of production. Also, the collaborations with science system partners and market partners in the enterprise group positively impacted on a firm's propensity to introduce onto the market new or significantly improved supporting activities. Surprisingly, a firm's collaboration was not statistically significant in affecting the probability to introduce onto the market a new or significantly improved logistic, delivery, or distribution system.

Lastly, the control variables for the Czech Republic also behaved in the way that one might expect. Locally owned firms in the Czech Republic are significantly likely to collaborate with other firms in the enterprise group, universities, and with government research organizations. Conversely, multinational firms did not collaborate with these partners for their innovations. Firm size was also positive and statistically significant in influencing both large firms and SMEs to collaborate with universities and 
government research organizations. This is consistent with similar findings by Cunningham and Link (2015), Bellucci and Pennacchio (2016), and Rõigas et al. (2018).

Table 2. Regression results for the Czech Republic.

\begin{tabular}{|c|c|c|c|c|c|c|}
\hline \multicolumn{3}{|c|}{ COENG } & \multicolumn{2}{|c|}{ COUNI } & \multicolumn{2}{|c|}{ COGOV } \\
\hline Variables & B (S.E) & $\operatorname{Exp}(B)$ & B (S.E) & $\operatorname{Exp}(B)$ & B (S.E) & $\operatorname{Exp}(B)$ \\
\hline \multicolumn{7}{|l|}{$\begin{array}{c}\text { Product } \\
\text { innovations }\end{array}$} \\
\hline INPDGD & $\begin{array}{l}2.023^{* * *} \\
(0.410)\end{array}$ & 7.561 & $\begin{array}{l}2.180 * * * \\
(0.226)\end{array}$ & 8.846 & $\begin{array}{l}2.007^{* * *} \\
(0.349)\end{array}$ & 7.440 \\
\hline INPDSV & $\begin{array}{l}0.711^{* *} \\
(0.280)\end{array}$ & 2.036 & $\begin{array}{l}0.396 * \\
(0.188)\end{array}$ & 1.486 & $\begin{array}{l}0.555 * \\
(0.244)\end{array}$ & 1.742 \\
\hline \multicolumn{7}{|l|}{$\begin{array}{c}\text { Process } \\
\text { innovations }\end{array}$} \\
\hline INPSPD & $\begin{array}{l}0.861^{* * *} \\
(0.279)\end{array}$ & 2.366 & $\begin{array}{l}0.650 * * * \\
(0.168)\end{array}$ & 1.915 & $\begin{array}{l}0.462 * \\
(0.241)\end{array}$ & 1.587 \\
\hline INPSLG & $\begin{array}{l}-0.136 \\
(0.274)\end{array}$ & 0.873 & $\begin{array}{c}0.079 \\
(0.178)\end{array}$ & 1.082 & $\begin{array}{c}0.203 \\
(0.241)\end{array}$ & 1.225 \\
\hline INPSSU & $\begin{array}{l}0.582 * \\
(0.255)\end{array}$ & 1.790 & $\begin{array}{l}0.356 * \\
(0.166)\end{array}$ & 1.428 & $\begin{array}{l}0.253 * * \\
(0.229)\end{array}$ & 1.288 \\
\hline \multicolumn{7}{|l|}{ Control variables } \\
\hline Locally owned & $\begin{array}{l}1.660^{* * *} \\
(0.465)\end{array}$ & 5.260 & $\begin{array}{l}1.158^{* * *} \\
(0.325)\end{array}$ & 3.182 & $\begin{array}{l}1.213 * * \\
(0.468)\end{array}$ & 3.364 \\
\hline Foreign owned & $\begin{array}{c}0.129 \\
(0.472) \\
\end{array}$ & 1.138 & $\begin{array}{c}0.197 \\
(0.317) \\
\end{array}$ & 1.218 & $\begin{array}{c}0.172 \\
(0.470)\end{array}$ & 1.188 \\
\hline Large firms & $\begin{array}{l}-0.183 \\
(0.410)\end{array}$ & 0.833 & $\begin{array}{l}1.382^{* * *} \\
(0.236)\end{array}$ & 3.981 & $\begin{array}{l}1.426^{* * *} \\
(0.348)\end{array}$ & 4.160 \\
\hline SMEs & $\begin{array}{l}-0.625 \\
(0.430)\end{array}$ & 0.535 & $\begin{array}{c}0.802 * * * \\
(0.227)\end{array}$ & 2.230 & $\begin{array}{l}0.738 \text { * } \\
(0.345)\end{array}$ & 2.092 \\
\hline $\begin{array}{c}\text { Constant } \\
\text { Model fit statistics }\end{array}$ & $\begin{array}{c}-5.014^{* * * *} \\
(0.635)\end{array}$ & 0.007 & $\begin{array}{c}-5.262 * * * \\
(0.396) \\
\end{array}$ & 0.005 & $\begin{array}{c}-6.212 * * * \\
(0.593)\end{array}$ & 0.002 \\
\hline Observations & \multicolumn{2}{|c|}{3069} & \multicolumn{2}{|c|}{3069} & \multicolumn{2}{|c|}{3069} \\
\hline -2loglikelihood & \multicolumn{2}{|c|}{518.91} & \multicolumn{2}{|c|}{1289.10} & \multicolumn{2}{|c|}{752.78} \\
\hline Cox \& Snell $\mathrm{R}^{2}$ & \multicolumn{2}{|c|}{0.131} & \multicolumn{2}{|c|}{0.181} & \multicolumn{2}{|c|}{0.068} \\
\hline Nagelkerke $\mathrm{R}^{2}$ & \multicolumn{2}{|c|}{0.467} & \multicolumn{2}{|c|}{0.373} & \multicolumn{2}{|c|}{0.253} \\
\hline$X^{2}$ & \multicolumn{2}{|c|}{386.66} & \multicolumn{2}{|c|}{552.98} & \multicolumn{2}{|c|}{218.25} \\
\hline
\end{tabular}

\section{Conclusions}

In this article, we analyzed firms' product and process innovations and whether they are influenced by their collaborations with science system partners, such as universities and other higher educational institutions, government research organizations, and other firms in the enterprise group. Firms' R\&D collaborations with these partners are known to be significant sources of firm-level innovations. For countries with moderate innovation potential, such as the Czech Republic and Hungary, the constant and sustained interactions among these actors can help to improve productivity and general innovation performances. Using the binomial logistic regression analysis, the researchers analyzed data from 6191 manufacturing industries in the Czech Republic and Hungary. The findings revealed that collaborations with science system partners and other enterprises in the firm's group are vital sources of a firm's product and process innovations in both countries. For the firms in both countries, their 
collaborations with other enterprises, universities, and government research institutions positively impacted on their probabilities to introduce onto the market new and improved goods as well as services.

We conclude that these R\&D collaborations are more likely to result in firms' process innovations, but the results were mixed for both countries. For the firms in Hungary, there was a positive statistical significance in their possibilities to significantly improve their production methods when they collaborated with universities. However, their collaborations with universities were not statistically significant in impacting on the prospects of introducing onto the market a new or significantly improved logistic, delivery, or distribution system in both countries. Additionally, our results also demonstrated that firms' collaborations with other enterprises in the group as well as with universities are more likely to result in their propensities to improve their supporting activities, such as accounting systems, operations, and their system maintenance.

Our results for the Czech Republic are similar to that of Hungary, but surprisingly, firms' collaborations with other enterprises in their group, universities, and government research centers were not statistically significant in affecting their possibilities to improve their logistics and delivery systems for their goods and services. It is possible these firms depend on other partners, such as suppliers of equipment and materials, for their logistics needs.

Again, we also conclude that foreign owned firms (multinationals) did not collaborate with other firms in the local enterprise group, universities, and government research institutions in both countries. These firms are probable to collaborate with other firms, universities, and government research institutions in the countries of their headquarters. On the contrary, firms with local ownerships were highly probable to collaborate with universities, government research organizations, and other firms that are part of their group in both countries. Our results also showed that large firms as well as SMEs in both countries collaborated with universities and government research institutions, but not with other partners in the enterprise group. These findings contribute to the increasing studies on firm-level innovations and R\&D collaborations in Visegrad countries.

This study provides practical implications for universities, industries, and government policy makers. We have shown that the science system consisting of higher educational institutions and other public research organizations is vital for firms' product and process innovations. We therefore recommend that governments in both countries provide the necessary support, such as funding and tax incentives, to these institutions to facilitate their collaborations and research potentials. Firms are also encouraged to collaborate with science system partners by providing funding to universities and other public research organizations to conduct research that can help to improve both their product and process innovations.

The following limitations have been noted by this study and they pose challenges which should be addressed in future studies. This study focused on just product and process innovations in the manufacturing industries in the Czech Republic and Hungary. We suggest that future studies should focus on organizational or marketing innovation within firms. This will help to conclude that $R \& D$ collaborations with these partners stimulate firms' innovations in general. Geographically, this study narrowly focused on the manufacturing industries in the Czech Republic and Hungary, and this may be replicated in other countries with different industries or sectors to help identify the variations in firms' sources of innovations. From the methodological perspective, there is a limitation to our statistical method and this might affect the validity and conclusion of our results. This study used the logistic regression model with binary dependent outcomes. We propose further studies to use other alternative robust statistical techniques, such as structural equation modeling (SEM), that can model more outcomes. Instead of the random interactions in the predictor variables in the logistics model, the SEM works on the assumption that all the independent variables are constant and do not interact. This can address likely problems, such as false positive and estimation bias, leading to more reliable conclusions that will help corroborate our findings.

Author Contributions: S.A.O. and J.S. contributed equally to prepare this manuscript. 
Funding: This research was generously supported by the Student Grant Competition of the University of Pardubice with grant number SGS_2019_018.

Conflicts of Interest: The authors declare no conflict of interest.

\section{References}

Banal-Estañol, Albert, Mireia Jofre-Bonet, and Cornelia Lawson. 2015. The double-edged sword of industry collaboration: Evidence from engineering academics in the UK. Research Policy 44: 1160-75. [CrossRef]

Belderbos, René, Martin Carree, Boris Lokshin, and Juan Fernández Sastre. 2015. Inter-temporal patterns of R\&D collaboration and innovative performance. The Journal of Technology Transfer 40: 123-37.

Bellucci, Andrea, and Luca Pennacchio. 2016. University knowledge and firm innovation: Evidence from European countries. The Journal of Technology Transfer 41: 730-52. [CrossRef]

Bolli, Thomas, and Martin Woerter. 2013. Competition and R\&D cooperation with universities and competitors. The Journal of Technology Transfer 38: 768-87.

Brada, Joseph C., and Inderji Singh. 2017. Firms Afloat and Firms Adrift: Hungarian Industry and Economic Transition: Hungarian Industry and Economic Transition. Abingdon-on-Thames: Routledge.

Braunerhjelm, Pontus, Ding Ding, and Per Thulin. 2018. The knowledge spillover theory of intrapreneurship. Small Business Economics 51: 1-30. [CrossRef]

Bstieler, Ludwig, Martin Hemmert, and Gloria Barczak. 2015. Trust formation in university-industry collaborations in the US biotechnology industry: IP policies, shared governance, and champions. Journal of Product Innovation Management 32: 111-21. [CrossRef]

Busom, Isabel, and Andrea Fernández-Ribas. 2008. The impact of firm participation in R\&D programmes on R\&D partnerships. Research Policy 37: 240-57.

Chun, Hyunbae, and Sung Bae Mun. 2012. Determinants of R\&D cooperation in small and medium-sized enterprises. Small Business Economics 39: 419-36.

Crespi, Gustavo, and Pluvia Zuniga. 2012. Innovation and productivity: Evidence from six Latin American countries. World Development 40: 273-90. [CrossRef]

Criaco, Giuseppe, Tommaso Minola, Pablo Migliorini, and Christian Serarols-Tarrés. 2014. "To have and have not": Founders' human capital and university start-up survival. The Journal of Technology Transfer 39: 567-93. [CrossRef]

Crossan, Mary M., and Marina Apaydin. 2010. A multi-dimensional framework of organizational innovation: A systematic review of the literature. Journal of Management Studies 47: 1154-91. [CrossRef]

Cunningham, James A., and Albert N. Link. 2015. Fostering university-industry R\&D collaborations in European Union countries. International Entrepreneurship and Management Journal 11: 849-60.

Damanpour, Fariborz. 2010. An integration of research findings of effects of firm size and market competition on product and process innovations. British Journal of Management 21: 996-1010. [CrossRef]

Dvořák, Petr, Stanislav Martinát, Dan Van der Horst, Bohumil Frantál, and Kamila Turečková. 2017. Renewable energy investment and job creation; a cross-sectoral assessment for the Czech Republic with reference to EU benchmarks. Renewable and Sustainable Energy Reviews 69: 360-68. [CrossRef]

Feller, Jan, Annaleena Parhankangas, Riitta Smeds, and Miia Jaatinen. 2013. How companies learn to collaborate: Emergence of improved inter-organizational processes in R\&D alliances. Organization Studies 34: 313-43.

Foray, Dominique, and Edward Steinmueller. 2003. On the economics of R\&D and technological collaborations: Insights and results from the project Colline. Economics of Innovation and New Technology 12: 77-91.

Forés, Beatriz, and César Camisón. 2016. Does incremental and radical innovation performance depend on different types of knowledge accumulation capabilities and organizational size? Journal of Business Research 69: 831-48. [CrossRef]

Hashi, Iraj, and Nebojša Stojčić. 2013. The impact of innovation activities on firm performance using a multi-stage model: Evidence from the Community Innovation Survey 4. Research Policy 42: 353-66. [CrossRef]

Hervas-Oliver, Jose Luis, Francisca Sempere-Ripoll, and Carles Boronat-Moll. 2014. Process innovation strategy in SMEs, organizational innovation and performance: A misleading debate? Small Business Economics 43: 873-86. [CrossRef]

Hottenrott, Hanna, and Cindy Lopes-Bento. 2014. (International) R\&D collaboration and SMEs: The effectiveness of targeted public R\&D support schemes. Research Policy 43: 1055-66. 
Huggins, Robert, Martin Jones, and Stevie Upton. 2008. Universities as drivers of knowledge-based regional development: A triple helix analysis of Wales. International Journal of Innovation and Regional Development 1 : 24-47. [CrossRef]

Ivanová, Eva, and Jana Masárová. 2018. Performance evaluation of the Visegrad Group countries. Economic Research-Ekonomska Istraživanja 31: 270-89. [CrossRef]

Johnston, Andrew, and Robert Huggins. 2017. University-industry links and the determinants of their spatial scope: A study of the knowledge intensive business services sector. Papers in Regional Science 96: 247-60. [CrossRef]

Kempton, Louise. 2015. Delivering smart specialization in peripheral regions: The role of Universities. Regional Studies, Regional Science 2: 489-96. [CrossRef]

Kergroach, Sandrine, Dirk Meissner, and Nicholas Spyridon Vonortas. 2018. Technology transfer and commercialisation by universities and PRIs: Benchmarking OECD country policy approaches. Economics of Innovation and New Technology 27: 510-30. [CrossRef]

Kim, Ki Chan, Changsoo Sohn, Thomas Roemer, and Ali Yassine. 2006. Configuration and coordination of activities within a supply chain: Exploring the synergy between modularity and information technology. International Journal of Automotive Technology and Management 6: 6-19. [CrossRef]

Laursen, Keld, and Ammon J. Salter. 2014. The paradox of openness: Appropriability, external search and collaboration. Research Policy 43: 867-78. [CrossRef]

Leydesdorff, Loet. 2012. The triple helix, quadruple helix, . . , and an N-tuple of helices: Explanatory models for analyzing the knowledge-based economy? Journal of the Knowledge Economy 3: 25-35. [CrossRef]

Liu, Yipeng, Christoph Lattemann, Yijun Xing, and David Dorawa. 2019. The emergence of collaborative partnerships between knowledge-intensive business service (KIBS) and product companies: The case of Bremen, Germany. Regional Studies 53: 376-87. [CrossRef]

Maietta, Ornella Wanda. 2015. Determinants of university-firm R\&D collaboration and its impact on innovation: A perspective from a low-tech industry. Research Policy 44: 1341-59.

Mohnen, Pierre, and Cathy Hoareau. 2003. What type of enterprise forges close links with universities and government labs? Evidence from CIS 2. Managerial and Decision Economics 24: 133-45. [CrossRef]

Nelson, Richard R. 2013. National Innovation Systems: It is. In Regional Innovation and Global. Abingdon-on-Thames: Routledge, pp. 19-34.

Odei, Samuel Amponsah, and Jan Stejskal. 2018a. The influence of knowledge sources on firm level innovation: The case of Slovak and Hungarian manufacturing firms. Central European Business Review 7: 61-74. [CrossRef]

Odei, Samuel Amponsah, and Jan Stejskal. 2018b. Factors Influencing Spin-off Activities at Universities: Empirical Evidence from the United Kingdom. Paper present at 21st International Colloquium on Regional Sciences, Kurdějov, Czech Republic, June 13-15; pp. 117-24.

Perkmann, Markus, Valentina Tartari, Maureen McKelvey, Erkko Autio, Anders Broström, Pablo D’Este, Riccardo Fini, Aldo Geuna, Rosa Grimaldi, Alan Hughes, and et al. 2013. Academic engagement and commercialisation: A review of the literature on university-industry relations. Research Policy 42: 423-42. [CrossRef]

Pietrobelli, Carlo, and Roberta Rabellotti. 2011. Global value chains meet innovation systems: Are there learning opportunities for developing countries? World Development 39: 1261-69. [CrossRef]

Prokop, Viktor, and Jan Stejskal. 2017. Different approaches to managing innovation activities: An analysis of strong, moderate, and modest innovators. Engineering Economics 28: 47-55.

Prokop, Viktor, Jan Stejskal, and Helena Kuvíková. 2017. The Different Drivers of Innovation Activities in European Countries: A Comparative Study of Czech, Slovak, and Hungarian Manufacturing Firms. Ekonomicky Casopis 65: 31.

Rõigas, Kärt, Pierre Mohnen, and Urmas Varblane. 2018. Which firms use universities as cooperation partners?-A comparative view in Europe. International Journal of Technology Management 76: 32-57. [CrossRef]

Sasidharan, Subash, and Vinish Kathuria. 2011. Foreign direct investment and R\&D: Substitutes or complements-A case of Indian manufacturing after 1991 reforms. World Development 39: 1226-39.

Tether, Bruce S. 2002. Who co-operates for innovation, and why: An empirical analysis. Research Policy 31: 947-67. [CrossRef] 
Tranmer, Mark, and Mark Elliot. 2008. Binary Logistic Regression. Cathie Marsh Centre for Census and Survey Research. Available online: http://hummedia.manchester.ac.uk/institutes/cmist/archive-publications/ working-papers/2008/2008-20-binary-logistic-regression.pdf (accessed on 30 September 2018).

Trantopoulos, Konstantinos, Georg von Krogh, Martin W. Wallin, and Martin Woerter. 2017. External knowledge and information technology: Implications for process innovation performance. MIS Quarterly 41: 287-300. [CrossRef]

Un, Chhomroth Annique, and Kazuhiro Asakawa. 2015. Types of R\&D collaborations and process innovation: The benefit of collaborating upstream in the knowledge chain. Journal of Product Innovation Management 32: 138-53.

Un, Chhomroth Annique, Alvaro Cuervo-Cazurra, and Kazuhiro Asakawa. 2010. R\&D collaborations and product innovation. Journal of Product Innovation Management 27: 673-89.

West, Joel, and Marcel Bogers. 2014. Leveraging external sources of innovation: A review of research on open innovation. Journal of Product Innovation Management 31: 814-31. [CrossRef]

$\mathrm{Wu}$, Jie. 2012. Technological collaboration in product innovation: The role of market competition and sectoral technological intensity. Research Policy 41: 489-96. [CrossRef]

$\mathrm{Wu}$, Jie. 2014. Cooperation with competitors and product innovation: Moderating effects of technological capability and alliances with universities. Industrial Marketing Management 43: 199-209. [CrossRef]

Zhang, Kai, Wu Zhao, Jie Wang, Ling Chen, Chen Wang, and Xin Guo. 2016. Research on knowledge support technology for product innovation design based on quality function knowledge deployment. Advances in Mechanical Engineering 8: 1-19. [CrossRef]

Zygmunt, Aleksandra. 2017. Innovation activities of Polish firms. Multivariate analysis of the moderate innovator countries. Oeconomia Copernicana 8: 505-21. [CrossRef]

(C) 2019 by the authors. Licensee MDPI, Basel, Switzerland. This article is an open access article distributed under the terms and conditions of the Creative Commons Attribution (CC BY) license (http://creativecommons.org/licenses/by/4.0/). 